\title{
Translation as a Biblical Ministry of Gospel Commission
}

\author{
Kparou Hanoukoume Cyril
}

\begin{abstract}
Language translation is analyzed in this article as a biblical ministry. The act of translation has been inherent to God's sovereign activity. Both Old and New Testament Patriarchs used translation to convey messages to their audiences. Translation is also expressed in the messages of the three angels of Revelation 14 as a means by which many "nations, tribes and peoples" would get to know the universal message of salvation. Through a systematic method of analysis, the paper defines translation in the biblical context with divine origin. Translators laboring in the mission serve as ministers of the word, and therefore, have the same prerogatives as any other minister of the gospel. This paper anchors the relevance of translation ministry in spreading the end-time messages from the biblical perspective. It examines the role of language translation in the gospel commission. It evaluates the importance of translation throughout the bible, ascertains and defines language translation as a divine act in God's redemptive plan, a biblical ministry of evangelism, a spiritual gift and an art.
\end{abstract}

Index Terms - Translation, Translator, Language, Translation Ministry.

\section{INTRODUCTION}

The prophetic commission in Revelation 14:6-7 contains the word "tongue", or "'language" (in Greek, glossa), which is listed among the destinations ("to every... language"') of the everlasting gospel. Four destinations are mentioned, "nations, tribes, peoples and ...languages". However, language seems strategic to the four elements mentioned. Nations, tribes and people are culturally demarcated by their languages. Since nations, tribes and people are determined by their languages, could it be that the commission to preach to them implies the use of their language as a vehicle of the everlasting gospel? In other words, how could it be possible for nations, tribes and people to hear the gospel if not preached in their languages? Could it be that language translation is implied as a ministry, to be carried out hand-in-hand with the gospel commission?

Throughout the Bible, Translation is used to reach people with God's message. Many Bible characters and writers could not have achieved their communication process without translation. In the same vein, the writings of Ellen G. White, a prolific writer, prophetess and reformer, shows how translation was key during the reformation era. She relayed on translation to reach out to people; she advocated for more translators to spread the message to all nations; she witnessed the Holy Spirit empowerment on translators and agreed that

Kparou Hanoukoume Cyril, $\mathrm{PhD}$, Department of Languages and Literary Studies, Babcock University, Ilishan-Remo, Ogun State, Nigeria the translators in the gospel ministry are (or aught to be inspired) by the Holy Spirit.

\section{DEFINITION AND THEORETICAL OVERVIEW}

\section{A. What is translation?}

Translation is from Latin word translatus, past participle of transferre "to transfer". Transferre is formed from two other Latin words, trans "across" and ferre "to bear" or "to carry" or "to convey". Therefore, the morphological meaning would be "to carry across". The fundamental meaning of translation is the conveying of a message across languages. The French equivalent is traduction, also from Latin traducere "to pass on". Traducere is also formed of two morphemes, tra- (diminutive of trans) "across", and dīcere "to lead".

The closely related word, "to interpret", from French interpréter, also has a Latin origin. It is formed from two morphemes, inter- "between", "into/upon each other", and pretis "to spread abroad".

Translation is a transfer of text, meaning and knowledge from one language to another. The langue of the original text is referred to as the Source Language (SL) and the language of destination is the Target Language (TL). It is also a transfer of cultural practice, whereas we interpret a Source Culture (SC) to a Target Culture (TC).

\section{B. Theories of Translation}

\section{- Translation as language competence}

Translation is at the core of every knowledge. Children learn by translating every social reality into their internal psychological system (Krauss, R. M., \& Chiu, C.-Y. 1998). Adults also have an internal language (system) which is the target of every external knowledge. From this point of view, humans are natural translators, since language and our capacity for language (language competence) are innate and universal (Chomsky, N. 2000). Another approach views translation as a premiere activity of language. In this line, Rotman (1995:187) asserts that "all [verbal] communication is translation". This view equates translation to language and suggests that every language activity implies translation.

- Semantic view

Also, translation is "an attempt to discover language meaning". Viewed in this angle, all linguistic branches of meaning are called on: semantics (study of linguistic meaning), pragmatics (study of contextual meaning) and semiotics, which studies the properties of signaling systems (Crystal 2008).

\section{- Linguistic view}

Translation is also a conversion of systems. Shannon \& 
Weaver (1949:10) describe language as "a communicative code" and "a system that pairs structurally". In this line, language being a system of signs, translation is the process of converting one system to another. Translators convert sound systems to other sound systems (phonology), grammars to other grammars, words to other words, etc.

\section{- Communication view}

The first objective of translation is to pass a message from one language to another. The communication approach of translation considers translation as a communication process where "the translator is the message conveyor" (Houbert, F. 1992). Another theoretical view considers translation as "a double act of communication" (Sonesson 2014). The principal idea of this view is that, the translator is both a receiver $(\mathrm{R})$ and a sender $(\mathrm{S})$ in the communication process. The translator is the receiver in one act of communication whereby the original author is the sender, and the sender in another act of communication whereby the receiver's language may be unknown to the original author.

\section{BIBLICAL BASIS OF TRANSLATION}

The Bible records that people spoke only one language until the Babel event. At Babel, God scattered people (this is the origin of language dialectalisation). Therefore, language barrier started at Babel. Before then, "The whole earth spoke one language and used the same words" (Gen. 11: 1, A.B.); but at Babel, "the Lord confused the language of the whole earth" (Gen. 11: 9, A.B.). It is obvious that after that event, translation would be used as a mediation among peoples.

However, the Scripture shows a relative existence of translation at the core of God's activity with language.

\section{A. God as Translator}

There is one particular stem in the Old Testament expressing the writing. It is kitab "to write, to transcribe" (to transcribe means "to write across", "to translate"), from which we have katōb "to write, imp.", "to transcribe" (Exodus 17:14), kātab (passive form), (Exodus 24:4), miktāb "the writing", "the transcription" (Exodus 32:16). The same verbal stem is used twice in Ezra 4:7, to refer to both the writing of the original letter and its translation: "and the writing [ketab] of the letter was written [katub] in the Syrian tongue and interpreted in the Syrian tongue." (Ezr 4:7 KJV). This means both the original writing and the translation are writings. So kitab also means "to translate". This verbal is used to refer to God's own act of writing on the tablets (Exod. $31: 18 ; 32: 15,16$ ), and to the book written in heaven (Exod. 32:32), and to God's order to Moses to write His commandments to the people, and also Moses act of writing (Exod. 17:14; 24:4). God Himself is a Translator, and therefore, if we assume that the ten commandments existed in heaven before they were given to Moses, and that, the language spoken in heaven is not Hebrew (the language of the ten commandments), then we can also interpret the last part of Exod. $31: 18$ as "... the words on them were translated by the finger of God"

\section{B. Patriarchs as translators}

Another Hebrew stem in the Bible, spr, generally found in

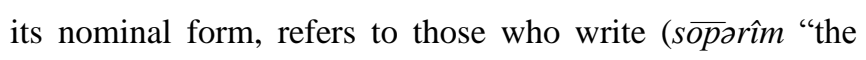
scribes", 1 Chron. 2:55, Neh. 13:13), and those who translate, such as Shimshai who translated the letter from Aramaic (Ezra 4:8). They are also referred to as secretaries (Ezra 4:8), or teachers (soper "scribe", "teacher" of the commandments).

The first s $\overline{o p} \hat{e}$ to be mentioned is Moses, who translated God's messages to Pharaoh, the Egyptian king, in the Egyptian language. After acknowledging he is not eloquent in the Egyptian language (he left Egypt for about forty years), God assured He would be with his mouth and give him the verb (Exod. 4:10-12). The Jewish culture in the Midrash also reckons that Moses taught and translated the torah, the five first books of the Bible, into seventy languages (https://www.chabad.org/parshah/article_cdo/aid/4460691/je wish/Moses-the-Translator.htm).

Apart from these evidences, other translation activities were mentioned in the Old Testament. Daniel, who had the faculty of "interpreting of dreams, and... hard sentences" (Daniel 5:12, KJV), translated the mysterious God-finger-written message to the evil king Belshazzar (Daniel 5:25-28). Joseph had a professional translator in his house (Gen. 42:23). Jonah who preached to the Ninivites, probably had to translate God's message into Akkadian language (Jonah 3).

\section{Jesus as a translator}

Some factors help us to apprehend the importance of languages and translation in Jesus ministry. The inscription on the cross was in "Aramaic, Greek and Latin" (John 19:20), which encapsulates the three most powerful languages of the time. Although it is not proven if Jesus spoke Latin, which was the elite Roman language, he certainly spoke Aramaic and Greek. Many scholars agree that Greek was the international language, while Aramaic was the vehicular language of the Jews (Encyclopedia Britannica, 2019; Greenspahn, 2003). Many Aramaic and Greek phrases are reported as quotes of Jesus, which suggest that Jesus spoke Aramaic as a mother tongue, and sometimes, used Greek. The examples are legion: "Abba, Father," (Mark 14:36), whereby "Abba" is in Aramaic and "Father" in Greek; "And about the ninth hour Jesus cried with a loud voice, saying, Eli, Eli, lama sabachthani? that is to say, My God, my God, why hast thou forsaken me?" (Mat 27:46 KJV).

Many quotes from Hebrew (Old Testament) are attributed to Jesus, therefore crediting Him a translation authorship. For example, He quoted the Hebraic Deuteronomy into Greek during the temptation by the devil: "But he answered and said, It is written, Man shall not live by bread alone, but by every word that proceedeth out of the mouth of God." (Mat 4:4 ASV, see Deut. 8:3); "Jesus said to him, 'It is written again, 'You shall not tempt the LORD your God."' (Mat 4:7 NKJ, see Deut. 6:16); "Then Jesus said to him, "Away with you, Satan! For it is written, 'You shall worship the LORD your God, and Him only you shall serve."' (Mat 4:10 NKJ, see Deut. 6;13).

The reason Jesus translated those passages was obvious. He wanted to use the messages to teach the common people in their common language. 


\section{TRANSLATION IN THE EARLY CHURCH}

One of the most prolific figures in the New Testament is Simon Peter. Just as his master, Jesus, the Apostle constantly used the Hebrew torah passages in his speeches and epistles in Greek. Many passages illustrate that translation act. "Because it is written, 'Be holy, for I am holy." (1 Peter 1:16 NKJ, Leviticus 11:44); "All flesh is as grass, and all the glory of man as the flower of the grass. The grass withers, And its flower falls away, but the word of the Lord endures forever." (1 Peter 1:24, 25 NKJ, Isaiah 40:6). All these quotations and many others, show how much translation was very important to Peter's ministry as an apostle (1 Peter 2:6 and Isaiah 28:16; 1 Peter 2:7 and Psalm 118:22-23; 1 Peter 2:22 and Isaiah 53:9; 1 Peter 2:24 and Isaiah 53:4-5; 1 Peter 3:10-12 and Psalm 34:12-16).

Apostle Paul, another great figure in the early church, quoted extensively from the Hebrew torah into his epistles in Greek. For example, "The just shall live by faith." (Rom 1:17 NKJ, Habakkuk 2:4); "I have made thee a father of many nations" (Rom 4:17 KJV, Genesis 17:5); "the things which the Gentiles sacrifice they sacrifice to demons and not to God" (1 Corinthians 10:20 NKJ, Deuteronomy 32:17); etc.

In the apostolic era in general, translation was viewed as both a divine gift and a ministry. 1 Cor. 12:10 mentions "diversity of languages" (bilingualism) "and interpretation [or translation]". 1 Cor. 12:30 mentions that one can be bilingual but could not translate. 1 Cor. 14:13 mentions that bilingualism and translation [or interpretation] are different gifts.

Also at Pentecost, the Holy Spirit is revealed as a translator par excellence. The apostles spoke and people heard him in diverse languages (Acts 2:8). As Apostle Peter reckons it in his speech, the Pentecostal Phenomenon is all about the Holy Spirit translating the Apostles speech to the multitude (Acts 2:17).

These numerous evidences of translation activities in the New Testament just prove one thing, the importance of translation in the gospel commission. As mentioned above, Jesus Himself used Hebraic Old Testament quotations which were reported in Greek (Matt. 4:4,6,10; 11:10; 21:13; 26:31; Marc 7:6; 14:27; Luc 4:4, Jean 6:45). His disciples did the same (John 2:17), and Paul translated many Old Testament quotations into Greek throughout Romans, Galatians, Corinthians, and Hebrews... This is enough evidence that the translation ministry is key to God's plan of salvation.

\section{ELLEN G. WHITE AND TRANSLATION}

Ellen Gould White, a prolific writer and important figure in the church reformation history, relayed on the translation in her ministry as a prophet and a writer. Many passages in her work testify of the importance of translation in her ministry and the gospel commission at large.

She relayed on translation to reach out to people:

"The Lord gave me strength and grace to address the people. Brother John Vuilleumier and an educated German translated into both languages for the benefit of the French and of the Germans. The Spirit of the Lord seemed to be in our midst. We then had [a] social meeting. Many good testimonies were borne. These testimonies were translated to us." (White 1990:330-331).

She advocated for more translators to spread the message to all nations:

"Men are now greatly needed who can translate and prepare our publications in other languages, so that the message of warning may go to all nations, and test them by the light of the truth, that men and women, as they see the light, may turn from transgression to obedience of the law of God. The books containing the reasons of our faith must be translated into all languages. This work must make more rapid progress than it has made." (White, 1922:214).

She witnessed the Holy Spirit empowerment on the translator and agreed that the translators in the gospel ministry are (or aught to be inspired) by the Holy Spirit:

"My appointment was at six o'clock. We had an interested audience. I spoke upon Christ riding into Jerusalem, and Brother Oyen translated just as fast as I gave him, sentence by sentence... I felt the deep moving of the Spirit of God upon my own heart and, by the promptness and earnestness of the way he translated, I believe he felt the Spirit of the Lord upon him." (White, 1993:334)

\section{TRANSLATION AND THE THREE ANGELS' MESSAGE}

"And I saw another angel fly in the midst of heaven, having the everlasting gospel to preach it... in every language saying... Fear God, and give glory to him; for the hour of his judgment is come". (Rev. 14:6-7).

The mention of "every language" in the first angel's message express the urgency of the translation ministry. Therefore, a God-fearing translator is a minister of the gospel; empowered by the Holy Spirit, he/she has the responsibility to translate and spread the message of the three angels in Revelation 14, which should be preached in "every language". By doing so, translators take part in the Ministry of the Word (diakonia tou logou) Acts 6:4.

The Bible also urge people to worship Christ "in every language": "and every language [glossa] confess that Jesus Christ is Lord, to the glory of God the Father." (Phi 2:11 NIV). This passage is directly pointing to a translation ministry and its importance in the worship of God on earth.

With more than 6500 languages in the world, it is obvious that without translation, many will not have the opportunity to hear the gospel. God-fearing translators are therefore needed in every language to carry on the end-time message as light-bearers, as emphasized by Ellen G. White: "Men are now greatly needed who can translate and prepare our publications in other languages, so that the message of warning may go to all nations, and test them by the light of the truth, that men and women, as they see the light, may turn from transgression to obedience of the law of God" (White, 1922:214-215).

\section{TRANSLATION FAITHFULNESS}

Translators have the immense responsibility to be faithful in the rendering of the message into other languages. 
Faithfulness is required from any minister of the Word.

"If any man shall add unto these things, God shall add unto him the plagues that are written in this book. And if any man shall take away from the words of the book of this prophecy, God shall take away his part out of the book of life, and out of the holy city, and from the things which are written in this book." (Rev. 22:19, also Math. 5:19).

The SDA Church policy states clearly, in the context of spirit of prophecy books: "The translation must be faithful and made from the original English text and shall convey to the readers the accurate picture of E.G.W. teachings." (WP, 358).

\section{CONCLUSION AND RECOMMENDATIONS}

Translation is a transfer of text, meaning and knowledge from one language to another. The translation is widely expressed in the bible as a spiritual gift, a ministry (diakonia tou logou) and an art, in relation to the biblical ministry of evangelism. Translation is viewed as having a central role in the worship of God by every nation, and the preparation of a people for the coming of Jesus-Christ.

Due to its importance, translation associations have been advocating the following recommendations:

\section{- Translators training}

Being aware of the importance of translation service, the subjacent need which arises is the need of translators. As Ellen G. White reckoned it, "men are now greatly needed who can translate and prepare our publications in other languages, so that the message of warning may go to all nations" (White, 1990:2), and "the books containing the reasons of our faith must be translated into all languages. This work must make more rapid progress than it has made." (White, 1903:106). Academic institutions, schools religious institutions should contribute to produce and train God-fearing translators.

\section{- Protection of translators and their literary work}

Schools, religious institutions and publishing houses should consider the international copyright about the protection of translators and their literary works, giving them equal rights to other literary scholars. According to the International Copyright Law, "The translator is therefore the holder of copyright in his/her translation and consequently has the same privileges as the author of the original work. The translator shall thus enjoy, with respect to his/her translation, all the moral rights of succession conferred by his/her authorship." (Records of the General Conference of United Nations, 1963)

\section{REFERENCES}

[1] Chomsky, N. 2000. "Minimalist Inquiries: The Framework". Step by step: essays on minimalist syntax in honor of Howard Lasnik. 89-155. Cambridge, Massachusetts: MIT Press.

[2] Crystal, D. 2008. A Dictionary of Linguistics and Phonetics, Blackwell Publishing.

[3] Dykstra, C. A. 1939. "The Quest for Responsibility". American Political Science Review, Vol. 33, No. 1.33 (1): 1-25. JSTOR 1949761. doi:10.2307/1949761.

[4] Frederick E. G. 2003. An Introduction to Aramaic. Second Edition, Society of Biblical Literature, Atlanta, Georgia.

[5] Encyclopedia Britannica, 2019. "Aramaic language Description, History, \& Facts".

[6] General Conference Working Policy, 2013-2014. General Conference of Seventh-day Adventist Church.
[7] Gutt, E. 1989. Translation and Relevance, $\mathrm{PhD}$ Thesis, University of London.

[8] Houbert, F. 1992. "Translation as a communication process", Translation Journal, Vol. 2, No. 3, (http://translationjournal.net/journal/05theory.htm).

[9] Krauss, R. M., \& Chiu, C.-Y. 1998. "Language and social behavior.” In D. T. Gilbert, S. T. Fiske, \& G. Lindzey (Eds.), The handbook of social psychology (p. 41-88). McGraw-Hill.

[10] Lee J. 2012. A Translation and Cross-Cultural Validation of the Academic Success Inventory for College Students, PhD Thesis, the Florida State University.

[11] Records of the General Conference of United Nations. 1963. Translator's Charter, Dubrovnik.

[12] Robinson, D. 2003. Becoming a Translator: An Introduction to the Theory and Practice of Translation, Second Edition, Routledge, London.

[13] Rotman, E. 1995. The inherent problems of legal translation: Theoretical aspects. Indiana International \& Comparative Law Review 6(1). 187-196.

[14] Shannon, C. E., \& Weaver, W. 1949. The mathematical theory of communication. Urbana: University of Illinois Press.

[15] Torres-Simón, E. and Anthony P. 2005. The professional backgrounds of translation scholars, Report on a survey. Intercultural Studies Group, Universitat Rovira i Virgili, Spain.

[16] Weissbort, D. and Astradur E. (eds). 2006. Translation: Theory and Practice, Oxford University Press, New York.

[17] White, E. G. 1990. Manuscript Releases, Review \& Herald Publishing Association, Volume 17, Nos. 1236-1300.

[18] White, E. G. 1922. Christian Experience and Teachings of Ellen G. White, Mountain View, CA: Pacific Press Publishing Association.

[19] White, E. G. 1983. The Publishing Ministry. Review \& Herald Publishing Association.

[20] White, E. G. 1993. Manuscript Releases, Review \& Herald Publishing Association, Volume 21, Nos. 1501-1598. 